\title{
Finding the way to the top: how the composition of oceanic mid-trophic micronekton groups determines apex predator biomass in the central North Pacific
}

\author{
C. Anela Choy ${ }^{1, *}$, Colette C. C. Wabnitz ${ }^{2}$, Mariska Weijerman ${ }^{3}$, \\ Phoebe A. Woodworth-Jefcoats ${ }^{4,5}$, Jeffrey J. Polovina ${ }^{4}$ \\ ${ }^{1}$ Monterey Bay Aquarium Research Institute, 7700 Sandholdt Road, Moss Landing, California 95039, USA \\ ${ }^{2}$ Institute for the Oceans and Fisheries, University of British Columbia, 2202 Main Mall, Vancouver \\ British Columbia V6T 1Z4, Canada \\ ${ }^{3}$ Joint Institute for Marine and Atmospheric Research, University of Hawaii at Manoa, 1000 Pope Road, Honolulu, \\ Hawaii 96822, USA \\ ${ }^{4}$ NOAA Pacific Islands Fisheries Science Center, 1845 Wasp Boulevard, Honolulu, Hawaii 96818, USA \\ ${ }^{5}$ Marine Biology Graduate Program, University of Hawaii at Manoa, 2525 Correa Road, Honolulu, Hawaii 96822, USA
}

\begin{abstract}
We updated and expanded a model of the pelagic ecosystem for the area of the central North Pacific occupied by the Hawaii-based longline fishery. Specifically, results from the most recent diet studies were used to expand the representation of the lesser-known non-target fish species (e.g. lancetfish, opah, snake mackerel) and 9 mid-trophic micronekton functional groups. The model framework Ecopath with Ecosim was used to construct an ecosystem energy budget and to examine how changes in the various micronekton groups impact apex predator biomass. Model results indicate that while micronekton fishes represented approximately $54 \%$ of micronekton biomass, they accounted for only $28 \%$ of the micronekton production. By contrast, crustaceans represented $24 \%$ of the biomass and accounted for $44 \%$ of production. Simulated ecosystem changes resulting from changes to micronekton groups demonstrated that crustaceans and mollusks are the most important direct trophic pathways to the top of the food web. Other groups appear to comprise relatively inefficient pathways or 'trophic dead-ends' that are loosely coupled to the top of the food web (e.g. gelatinous animals), such that biomass declines in these functional groups resulted in increased biomass at the highest trophic levels by increasing energy flow through more efficient pathways. Overall, simulated declines in the micronekton groups resulted in small changes in biomass at the very top of the food web, suggesting that this ecosystem is relatively ecologically resilient with diverse food web pathways. However, further understanding of how sensitive micronekton are to changes in ocean chemistry and temperature resulting from climate change is needed to fully evaluate and predict potential ecosystem changes.
\end{abstract}

KEY WORDS: Forage species · Hawaii longline fishery $\cdot$ North Pacific Subtropical Gyre $\cdot$ Ecopath with Ecosim $\cdot$ Ecosystem modeling $\cdot$ Climate change $\cdot$ Marine food webs

\section{INTRODUCTION}

The pelagic ecosystem of the central North Pacific (CNP) encompasses a substantial portion of the North Pacific Subtropical Gyre, which is Earth's single largest circulation feature and most expansive living

\footnotetext{
*Corresponding author: anela@mbari.org
}

space (Roemmich \& McCallister 1989, Karl 1999). In addition to performing critical ecosystem services such as global climate regulation, the CNP pelagic ecosystem houses large-scale commercial fisheries that target high-value tuna and billfish species (He et al. 1997, Bigelow et al. 2002, Sibert et al. 2006).

(0) The authors 2016. Open Access under Creative Commons by Attribution Licence. Use, distribution and reproduction are unrestricted. Authors and original publication must be credited. 
Persistent harvest of predatory fish biomass has imparted measurable changes to CNP pelagic ecosystem structure, while environmental variability has also been reported to affect predatory fish populations and fishery removal patterns in recent decades (Doney et al. 2012). At the top of the food web, for example, decadal shifts in both target and non-target fish species and size composition have been documented from the Hawaii-based longline fishery (Polovina et al. 2009, Polovina \& Woodworth-Jefcoats 2013). Long-term changes at the base of the CNP pelagic food web have also been reported, namely decreasing levels of surface chlorophyll in oceanic subtropical gyres (Polovina et al. 2008, Gregg \& Rousseaux 2014) accompanied by changes in phytoplankton community composition (Karl et al. 2001, Corno et al. 2007, Sherwood et al. 2014).

Comprehensive understanding of overall ecosystem impacts and potential fishery management implications due to widespread fishery and environmental changes is still incomplete. Increasing calls have been made for ecosystem-based fishery management, a holistic approach that aims to maintain the ecological integrity of a system by accounting for cumulative natural and anthropogenic impacts to all ecosystem components in management decisions (Brodziak \& Link 2002). Forage or mid-trophic species (hereafter referred to as micronekton), which form critical trophic links transferring production from primary and secondary producers up to large apex species, are perhaps one of the most critically understudied components of pelagic food webs.

Micronekton communities are generally highly diverse, consisting of small but mobile crustaceans, cephalopods, fishes, and gelatinous animals $\sim 2$ to $20 \mathrm{~cm}$ in size (Seki \& Polovina 2001, Brodeur \& Yamamura 2005). Many micronekton animals are primary prey of marine mammals, seabirds, and commercially important tunas and billfishes (e.g. Harrison \& Seki 1987, Pauly et al. 1998, Watanabe et al. 2009). Trophic modes employed by micronekton can range widely from zooplanktivory to piscivory, including omnivory, cannibalism, and opportunistic feeding on variable prey bases (e.g. Clarke 1973, 1974, Mauchline \& Gordon 1986, Passarella \& Hopkins 1991). Biological production generated by phytoplankton in surface waters can thus be partitioned through multiple, complex pathways as energy flows through diverse micronekton groups up to apex predators. Recent studies suggest that mesopelagic micronekton fishes dominate global fish biomass, and together with crustacean, mollusk, and gelatinous micronekton species perform critical roles in the marine bio- geochemical cycling of carbon (Davison et al. 2013, Irigoien et al. 2014).

Micronekton are particularly difficult to study as their primary habitat generally extends from beneath epipelagic waters $(>200 \mathrm{~m}$ ) to depths throughout the mesopelagic and bathypelagic ( 200 to $4000 \mathrm{~m}$ ). Different micronekton species have varying degrees of mobility, but most are agile enough to detect and avoid traditional mid-water sampling gear (Gjosaeter \& Kawaguchi 1980, Koslow et al. 1997, Kaartvedt et al. 2012). Thus, studies examining micronekton have customarily been descriptive in nature, focusing on various aspects of community composition (e.g. species distribution, behavior, abundance, and biomass) or examining the diets of some of the most commonly captured species (e.g. Clarke 1973, 1974, Maynard et al. 1975). However, predicted environmental changes to oceanic ecosystems (e.g. ocean acidification, expanding oxygen minimum zones, ocean warming, increased stratification) may disproportionately affect certain types of micronekton, thereby shunting or rerouting previously available flows of biological production available to apex species. For example, calcifying organisms such as pelagic crustaceans or the early life stages of cephalopods and other mollusks may be particularly sensitive to changes in oceanic carbonate chemistry (Fabry et al. 2008, Whiteley 2011, Kaplan et al. 2013a). Thus, focused studies examining the specific food web relationships of mid-trophic micronekton to economically valued apex species are needed amidst a changing marine environment.

Sampling difficulties associated with accessing remote mid-water environments inhibit our ability to fully characterize the ecosystem dynamics of midtrophic communities, let alone anticipate potential ecosystem impacts given known environmental variability and fishing pressures. Ecosystem modeling is an important and widely used approach for exploring system dynamics and the possible responses of those dynamics to specific environmental and anthropogenic perturbations (Plagányi \& Butterworth 2004, Colléter et al. 2015). This method is particularly important for vast, ecologically complex pelagic systems for which empirically based synthesis studies are especially challenging. Thus, the primary objective of this study was to examine the ecological roles of mid-trophic micronekton functional groups in transferring energy to the top of the CNP pelagic food web. We compiled best available biological information to update and expand the representation of mid-trophic groups and their primary predators for a CNP model previously developed by Howell et al. 
(2013), itself built based on previous iterations (Kitchell et al. 1999, Cox et al. 2002a,b). Model results provide a better understanding of the main throughways for energy flow within the CNP pelagic ecosystem and of how these trophic pathways may be altered given anticipated future climate variability and change.

\section{MATERIALS AND METHODS}

\section{Study area and ecosystem description}

The study area encompasses offshore waters of the central North Pacific Ocean used by the Hawaiibased pelagic longline fishery, from approximately $170^{\circ} \mathrm{E}$ to $150^{\circ} \mathrm{W}$ and $10^{\circ} \mathrm{N}$ to $40^{\circ} \mathrm{N}$, with the northern boundary defined by the $17^{\circ} \mathrm{C}$ sea surface temperature isotherm (Fig. 1). The study area directly follows that of Howell et al. (2013), covering a surface area of roughly $13275700 \mathrm{~km}^{2}$ in which the vast majority of Hawaii longline fishery sets are made (Fig. 1). These open ocean waters are seaward of any continental shelves and surround the Hawaiian Archipelago, forming a substantial portion of the North Pacific Subtropical Gyre biome. This biome is characterized by oligotrophy (low levels of bioavailable nutrients), generally low surface-chlorophyll levels $\quad<0.1 \mathrm{mg}$ $\mathrm{m}^{-3}$ ), mesoscale oceanographic variability, seasonally variable surface mixed layers, strong water column stratification, and complex microbial loop dynamics (reviewed in Karl 1999). Despite generally low productivity, these waters house a diverse pelagic community of typically 5 or more trophic levels, with micronekton fishes, cephalopods, crustaceans, and

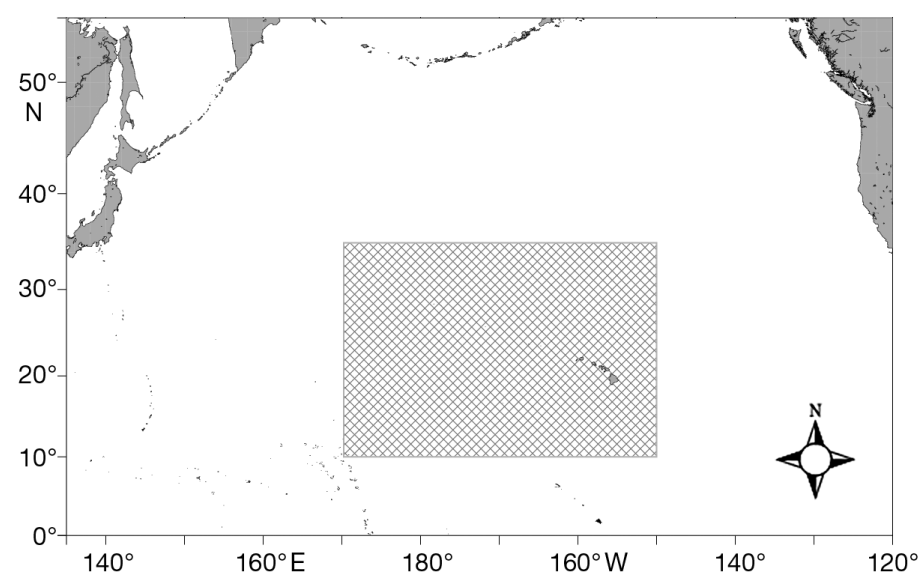

Fig. 1. The central North Pacific, showing the core area of the Hawaii-based longline fishing grounds and model study region (cross-hatched area) gelatinous animals occupying intermediate trophic levels (Maynard et al. 1975), and sharks, tuna, and billfishes occupying the highest trophic levels (Seki \& Polovina 2001).

\section{Ecosystem modeling approach}

All trophic and temporal model explorations were conducted with the Ecopath with Ecosim software package (EwE, version 6.4.10486.0), a well documented and widely used ecosystem modeling platform (Polovina 1984, Pauly et al. 2000, Christensen \& Walters 2004). Ecopath models the static state of an ecosystem, balancing mortality sources (e.g. migration, predation, fishery removals) with net production for food web functional groups defined and parameterized by the user. Ecosim is the dynamic expression of Ecopath, allowing for temporal explorations of biomass and system changes in relation to growth, ecological efficiency, and consumption, relative to the same sources of mortality (see Christensen et al. 2008 for underlying master equations). For each defined functional group, in addition to diet (relative to the other defined food web groups), EwE models require 3 of the 4 following biological input parameters: biomass (B), production to biomass ratio (P:B), consumption to biomass ratio $(\mathrm{Q}: \mathrm{B})$, and ecotrophic efficiency (EE).

We directly expanded and modified the Ecopath component of the Hawaii Longline Fishing Grounds EwE model (HLFG1) built by Howell et al. (2013), which originally contained 28 functional groups and 3 fishing fleets (international longline, international purse seine, and US albacore troll fisheries). Thirteen functional groups were added to improve Ecopath model parameterization of the CNP pelagic ecosystem and work undertaken included literature synthesis of the feeding and trophic ecology of these additional groups and adjustments based on updated biological data for the other 28 functional groups. Specifically, our Ecopath model was expanded to include a total of 41 functional groups, increasing the representation of micronekton groups (from 5 groups to 9 total), and intermediate mesopredator groups (e.g. adding 'opah' and 'snake mackerel and escolar' as separate individual groups) for which updated diet information from the CNP exists (Table 1). Comprehensive fisheries catch, effort, and species length and weight data were preserved intact from Howell et al. (2013).

Functional groups were assigned by aggregating species that are ecologically and functionally similar in terms of behavior, diet, preferred habitat, and gen- 
Table 1. Biological input and output parameters for the ecosystem components in the central North Pacific Ecopath with Ecosim ecosystem model. Parameters in bold represent model-estimated output. B: biomass (tons km ${ }^{-2}$ ); P:B: production: biomass ratio $\left(\mathrm{yr}^{-1}\right)$; Q:B: consumption:biomass ratio $\left(\mathrm{yr}^{-1}\right) ; \mathrm{P}$ : production $\left(\mathrm{t} \mathrm{km}^{-2} \mathrm{yr}^{-1}\right)$; EE: ecotrophic efficiency; TL: trophic level. Functional groups with italicized names are groups additional to the last model iteration (Howell et al. 2013)

\begin{tabular}{|c|c|c|c|c|c|c|c|}
\hline & Functional group & $\mathrm{B}$ & $\mathrm{P}: \mathrm{B}$ & $\mathrm{Q}: \mathrm{B}$ & $\mathrm{P}$ & EE & $\mathrm{TL}$ \\
\hline 1 & Blue sharks & 0.0019 & 0.42 & 1.50 & 0.0008 & 0.476 & 4.95 \\
\hline 2 & Other sharks & 0.0020 & 0.32 & 2.82 & 0.0006 & 0.264 & 5.14 \\
\hline 3 & Broadbill swordfish & 0.0018 & 0.35 & 3.30 & 0.0006 & 0.759 & 4.52 \\
\hline 4 & Blue marlin & 0.0005 & 0.47 & 3.80 & 0.0002 & 0.683 & 4.95 \\
\hline 5 & Striped marlin & 0.0006 & 0.47 & 3.80 & 0.0003 & 0.553 & 4.84 \\
\hline 6 & Other billfishes & 0.0005 & 0.81 & 6.07 & 0.0004 & 0.400 & 4.77 \\
\hline 7 & Small billfishes & 0.0700 & 1.00 & 10.00 & 0.0700 & 0.600 & 4.61 \\
\hline 8 & Baleen whales & 0.0780 & 0.08 & 7.40 & 0.0061 & 0.000 & 3.77 \\
\hline 9 & Toothed whales & 0.0349 & 0.03 & 13.00 & 0.0010 & 0.154 & 4.70 \\
\hline 10 & Bigeye tuna & 0.0041 & 0.50 & 8.20 & 0.0020 & 0.305 & 4.81 \\
\hline 11 & Juvenile bigeye tuna & 0.0030 & 0.60 & 14.70 & 0.0018 & 0.786 & 4.37 \\
\hline 12 & Yellowfin tuna & 0.0196 & 0.40 & 10.60 & 0.0079 & 0.309 & 4.62 \\
\hline 13 & Juvenile yellowfin tuna & 0.0011 & 0.50 & 26.33 & 0.0006 & 0.840 & 4.13 \\
\hline 14 & Albacore tuna & 0.0152 & 0.40 & 9.60 & 0.0061 & 0.430 & 4.68 \\
\hline 15 & Juvenile albacore tuna & 0.0182 & 0.35 & 14.92 & 0.0064 & 0.750 & 4.09 \\
\hline 16 & Skipjack tuna & 0.0208 & 1.90 & 14.09 & 0.0395 & 0.194 & 4.32 \\
\hline 17 & Juvenile skipjack tuna & 0.0643 & 5.50 & 30.00 & 0.3535 & 0.110 & 3.92 \\
\hline 18 & Mahi-mahi & 0.0761 & 1.00 & 8.48 & 0.0761 & 0.800 & 4.67 \\
\hline 19 & Lancetfish & 0.9031 & 0.47 & 4.00 & 0.4244 & 0.600 & 4.34 \\
\hline 20 & Opah & 0.0535 & 0.22 & 3.50 & 0.0118 & 0.600 & 4.72 \\
\hline 21 & Snake mackerel and escolars & 1.1579 & 0.28 & 3.88 & 0.3199 & 0.600 & 4.46 \\
\hline 22 & Other large pelagic fishes & 2.8368 & 0.60 & 4.13 & 1.7021 & 0.900 & 4.02 \\
\hline 23 & Sea birds & 0.0003 & 1.00 & 80.00 & 0.0003 & 0.230 & 4.66 \\
\hline 24 & Sea turtles & 0.0029 & 0.12 & 19.80 & 0.0004 & 0.156 & 3.66 \\
\hline 25 & Small epipelagic fishes & 2.0000 & 2.40 & 9.00 & 4.8000 & 0.830 & 3.53 \\
\hline 26 & Zooplanktivorous micronekton fishes & 5.8000 & 2.10 & 8.00 & 12.1800 & 0.964 & 3.20 \\
\hline 27 & Carnivorous micronekton fishes & 3.9000 & 1.70 & 6.00 & 6.6300 & 0.994 & 4.07 \\
\hline 28 & Decapod crustaceans & 2.4951 & 4.80 & 25.00 & 11.9765 & 0.910 & 2.92 \\
\hline 29 & Other crustaceans & 3.0427 & 8.00 & 25.00 & 24.3414 & 0.950 & 2.93 \\
\hline 30 & Predatory gelatinous & 1.8644 & 5.01 & 25.05 & 9.3408 & 0.702 & 3.44 \\
\hline 31 & Filter-feeding gelatinous & 0.9120 & 5.40 & 20.00 & 4.9249 & 0.934 & 2.11 \\
\hline 32 & Epipelagic mollusks & 0.9000 & 3.50 & 10.00 & 3.1500 & 0.965 & 4.07 \\
\hline 33 & Mesopelagic mollusks & 1.6000 & 4.00 & 10.00 & 6.4000 & 0.995 & 3.26 \\
\hline 34 & Bathypelagic fishes & 2.9000 & 1.50 & 2.45 & 4.3500 & 0.897 & 3.59 \\
\hline 35 & Mesozooplankton & 8.4927 & 20.00 & 30.00 & 169.854 & 0.980 & 2.44 \\
\hline 36 & Microzooplankton & 11.1300 & 25.00 & 60.00 & 278.250 & 0.447 & 2.00 \\
\hline 37 & Diatoms & 0.2300 & 120.00 & - & 27.600 & 0.602 & 1.00 \\
\hline 38 & Diazotrophs & 0.4100 & 120.00 & - & 49.200 & 0.338 & 1.00 \\
\hline 39 & Other large phytoplankton & 0.4900 & 120.00 & - & 58.800 & 0.451 & 1.00 \\
\hline 40 & Small phytoplankton & 10.9400 & 180.00 & - & 1969.200 & 0.342 & 1.00 \\
\hline 41 & Detritus & 100 & - & - & 0.0000 & 0.092 & 1.00 \\
\hline
\end{tabular}

eral production and consumption. The 9 micronekton groups were defined based on classic size fractions of oceanic plankton and nekton $(2-20 \mathrm{~cm})$ from Sieburth et al. (1978) and general trophic guilds from known diet information. Descriptions of the micronekton groups with representative members are provided in Table 2. Modeled phytoplankton biomass for 4 primary producer groups ('diatoms', 'diazotrophs', 'other large phytoplankton' 5-200 $\mu \mathrm{m}$, and 'small phytoplankton' $0.2-5 \mu \mathrm{m}$ ) were obtained from the NOAA GFDL prototype Earth System Model (ESM2.1). ESM2.1 links a climate model (CM2.1; Delworth et al. 2006, Gnanadesikan et al. 2006) to a biogeochemical model, Tracers of Phytoplankton with Allometric Zooplankton (TOPAZ; Dunne et al. 2005), and data used represent the IPCC Special Report on Emissions Scenario A2 (for details, see Polovina et al. 2011, Howell et al. 2013). 


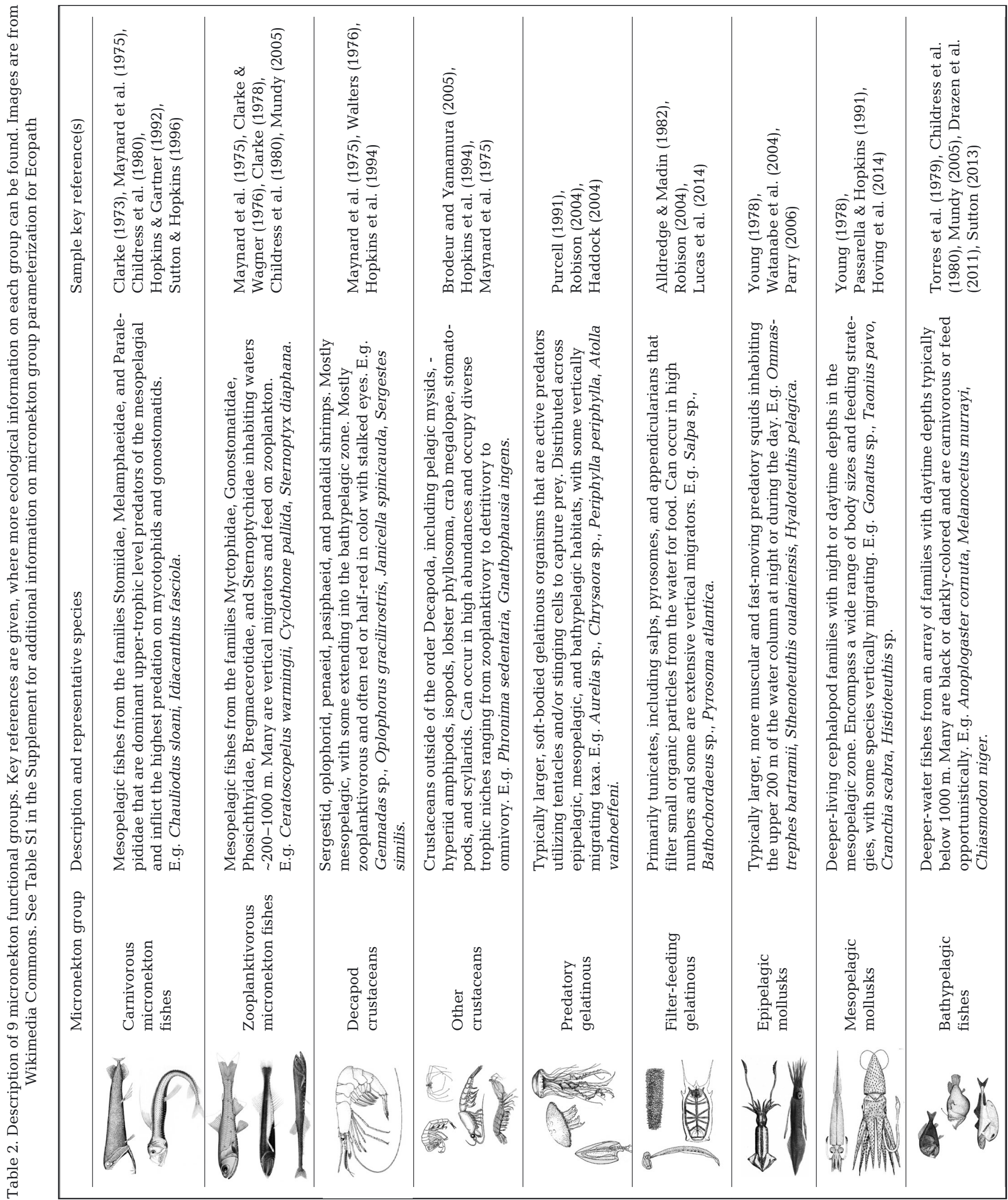


Biological input parameters for the 41 functional groups were taken, where possible, from Howell et al. (2013) and data that informed the development of the HLFG1 model. Otherwise, best-available biological information for the region was derived and synthesized from field studies, stock assessments, fishery reports, communications with physiological and ecological experts, related EwE pelagic ecosystem models (Cox et al. 2002b, Kitchell et al. 2002, Essington 2006, Griffiths et al. 2010), and FishBase (Froese \& Pauly 2015). Functional groups, including representative species and the source(s) of biological input parameters are detailed in Table S1 in the Supplement (at www. int-res.com/articles/suppl/m549p009_supp.pdf). The diet matrix is provided in Table S2 in the Supplement and was populated using best available stomach content data from the CNP (see Table S1 for sources). Whenever possible, diet contributions for groups containing multiple species were scaled according to the relative biomass contributions of individual species to the overall group.

\section{Ecosim perturbation scenarios}

We used Ecosim to evaluate and quantify the relative trophic importance of the 9 distinct micronekton functional groups by independently reducing the biomass of each of the 9 groups by $30 \%$ of initial biomass levels over a $50 \mathrm{yr}$ period. A $50 \mathrm{yr}$ time period was chosen after observing that food web responses stabilized over this time frame. Biomass reductions of $30 \%$ of initial model biomass levels were chosen in line with a number of common fishery management targets for non-forage stocks (Clark 2002, Kaplan et al. 2013b). Reduction of micronekton biomass for the perturbation scenarios was achieved using constant fishing mortality levels. During the Ecosim scenarios, phytoplankton biomass was kept constant (simulating no bottom-up control), as were fishery removals for commercially harvested fish species (simulating constant top-down mortalities). To further reduce top-down and bottom-up influences, as well as potentially confounding species-specific interactions, all vulnerability values were set to the default value of 2 (Mackinson et al. 2009). Once it was determined which 2 micronekton groups elicited the strongest responses to species at the top of the food web, those 2 micronekton groups were simultaneously reduced by $30 \%$ of their initial biomass levels for a 50 yr period using Ecosim ('crustaceans and mollusks' scenario).

\section{Model balancing and sensitivity analysis}

Before balancing the updated model, we performed a pre-balance check of all input parameters (Link 2010, Heymans et al. 2016). Each of the input parameters was plotted against the species trophic level ranked from lowest to highest (Fig. S1 in the Supplement at www.int-res.com/articles/suppl/m549p009_ supp.pdf). Where biomass (B), production to biomass ratio $(\mathrm{P}: \mathrm{B})$, or consumption to biomass ratio $(\mathrm{Q}: \mathrm{B}) \mathrm{di}-$ verged from the slope line, values were doublechecked for data integrity and adjusted if necessary. Additionally, we diagnosed model input parameters by examining the $\mathrm{P}: \mathrm{Q}$ ratio, or the gross food conversion efficiency, which should fall between approximately 0.1 and 0.3 (Darwall et al. 2010). If necessary, and based entirely upon available reference materials and/or informed expert opinion, $\mathrm{P}: \mathrm{B}$ or $\mathrm{Q}: \mathrm{B}$ values were adjusted to reach $P: Q$ values between 0.1 and 0.3. Changes resulting from the pre-balance checks are noted in Fig. S1.

To test the sensitivity of the model output to the vulnerability $(v)$ value (2) used in our simulations, we compared this output to that with stronger bottom-up forcing $(v=1)$ and stronger top-down forcing $(v=10)$. For each perturbation scenario in Ecosim, additional simulations were run with the vulnerability of the relevant micronekton functional group (or 2 groups in the case of the 'crustaceans and mollusks' scenario) changed to 1 and to 10 .

\section{Trophic guild analysis}

To aid in interpreting responses of food web components to micronekton perturbation scenarios, a principal components analysis (PCA) was conducted using the balanced model diet matrix, which parameterizes the exchange of biomass among food web components through feeding interactions. PCA was performed on non-transformed percent composition (by weight) diet data, and the principal components were used to determine the prey items (as functional groups) contributing most to separation between observed predator groups. PCA results conducted on the diet matrix are presented to guide interpretation of model perturbation results. Hierarchical cluster analyses performed on Bray-Curtis similarity matrices were used to augment PCA results by overlaying clusters on principal component plots using $60 \%$ similarity cut-offs (Clarke \& Gorley 2006). PCA and cluster analyses were performed using Primer 6 (Primer-E). 


\section{RESULTS}

\section{Ecopath model}

The model comprises 41 functional groups, organized into approximately 5 trophic levels, with sharks and billfishes occupying the top of the CNP pelagic food web. Selected biological model parameters for all functional groups are shown in detail in Table 1 (see also Table S1 in the Supplement for referenced literature sources and full group descriptions). We balanced the Ecopath model through small adjustments to the model diet matrix (generally $<5 \%$ adjustment per predator-prey group) (Fig. S1 in the Supplement). Changes to the model diet matrix are the typical first step in obtaining a balanced model because diet studies of diverse pelagic animals have cited flexibility in feeding habits due to changes in prey and environmental variability, among other factors (e.g. Young et al. 2010, Choy et al. 2013, Olson et al. 2014). Based on results of our pre-balance check, we made additional changes to the biomasses and Q:B values of 2 groups (changes detailed in Fig. S1). Biomass estimates from fishery-dependent stock assessments and midwater trawling studies commonly acknowledge potential sources of error that may lead to inaccurate biomass estimations. Biomass underestimates are frequently reported for many micronekton groups sampled with oceanic trawling equipment, the primary literature source for our original biomass estimates. Within the final balanced Ecopath model, the 4 primary producer groups accounted for $19 \%$ of the total system biomass, while apex predator groups (trophic levels $>4.0$ ) accounted for $8 \%$ of total system biomass. Detailed information on the 9 micronekton functional groups, the key focus of our study, is presented in Table 2, including their primary species composition and the key literature references utilized to parameterize each group.

\section{Model sensitivity analyses}

Sensitivity analyses revealed that the simulated responses to ecosystem change were not an artifact of chosen vulnerability values. As expected, lowering vulnerability values of the micronekton groups reduced their consumption by predators and vice versa, but in general, biomass changes using different vulnerabilities were less than $5 \%$ (Fig. S2 in the Supplement at www.int-res.com/articles/suppl/ m549p009_supp.pdf). In all cases, changes in predator and prey biomasses were in the direction ex- pected given the change in vulnerability and scaled with percent diet composition of the impacted groups. Thus, simulation results are not expected to drastically change given different vulnerability values.

\section{Feeding similarities}

The backbone of an Ecopath model consists primarily of the predator-prey interactions between functional groups as parameterized by the diet matrix. For this reason, we compared the diets of each of the functional groups using PCA. For more detailed interpretation, 2 separate PCA analyses were conducted: one targeting the top of the food web (i.e. functional groups with computed trophic levels greater than 3.5), and one targeting only the 9 micronekton functional groups that are the primary focus of this study. For the micronekton, principal component 1 (PC1) explained most of the variance in diet $(51.2 \%)$, with PC2 explaining $18.9 \%$ of the variance. For the top of the food web, PC1 explained only $31.9 \%$ of the variance, while PC2 explained $23 \%$ of the variance.

The micronekton functional groups have distinct diets according to their consumption of mesopelagic zooplankton (along the PC1 axis) and micronekton crustaceans, as well as detritus and some phytoplankton groups (along the PC2 axis) (Fig. 2A). 'Zooplanktivorous micronekton fishes' and 'other crustaceans', along with the 'decapod crustaceans' and 'predatory gelatinous' groups, clustered most closely together based on their heavy consumption of mesopelagic zooplankton. As expected, the 'filter-feeding gelatinous' group (e.g. salps, doliolids, larvaceans) was the most different in PCA space, with unique consumption of detritus and phytoplankton. Though not significantly clustered together at the $60 \%$ similarity level, 'epipelagic mollusks' and 'mesopelagic mollusks' had diets similar to that of the 'bathypelagic fish' group, with all 3 groups feeding heavily on combinations of different micronekton crustaceans (e.g. amphipods) and fishes (e.g. myctophids and gonostomatids).

The main prey groups contributing most to the separation of the predator functional groups along PC1 are 'epipelagic mollusks' and 'mesopelagic mollusks' (Fig. 2B, see overlain vectors). Separation in predator feeding along $\mathrm{PC} 2$ can be attributed to consumption of 'other crustaceans' (positive PC2 scores) as well as 'other large pelagic fishes' and 'mesopelagic mollusks' (negative PC2 scores). Selected functional 

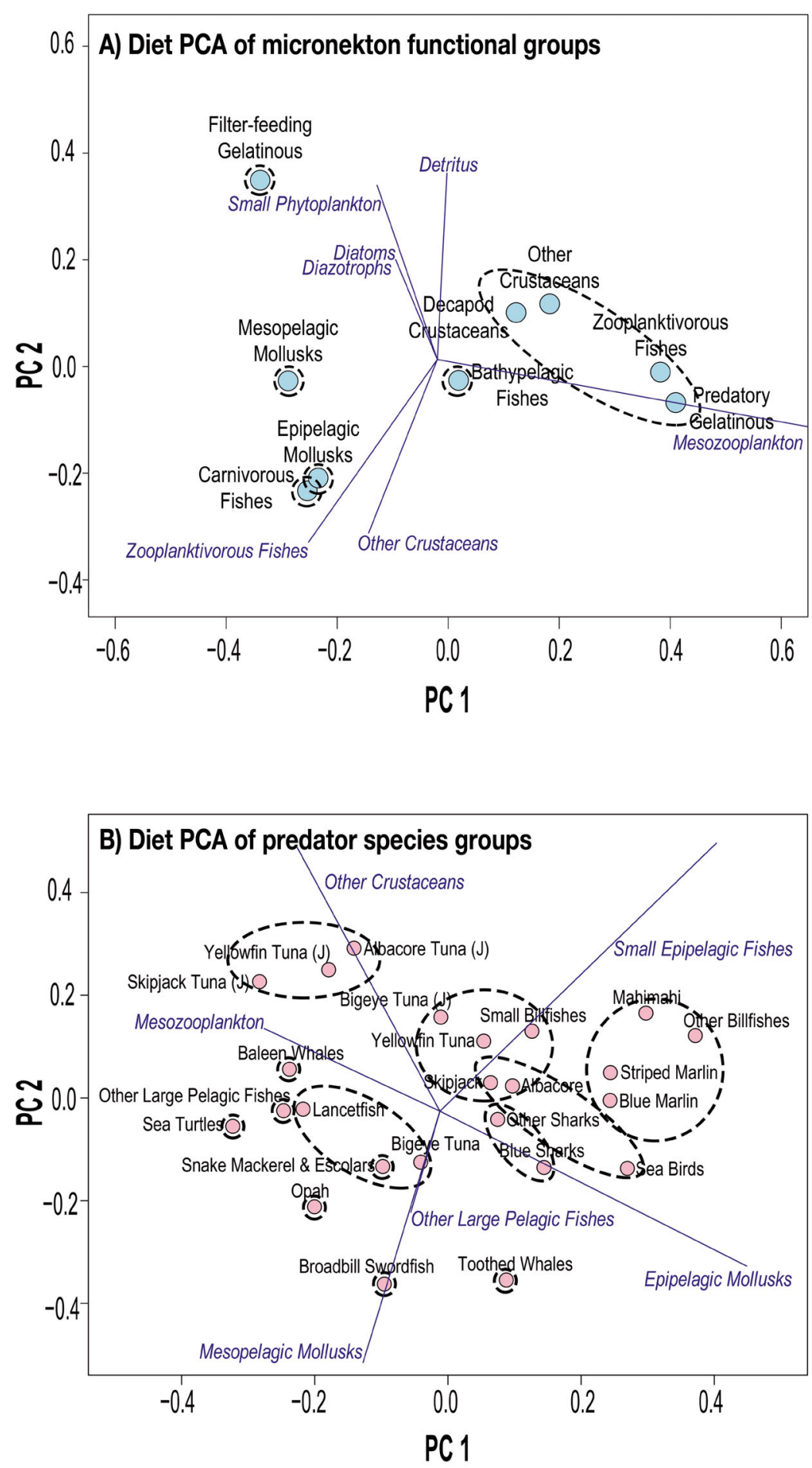

Fig. 2. Biplot of the first and second principal components (PC) derived from the percent diet composition of pelagic food web functional groups. Trophic guilds of food web groups with similar diets are shown for (A) 9 micronekton functional groups (blue circles) alongside zooplankton and phytoplankton functional groups, and (B) predator groups (pink circles) at trophic level 3.5 and greater. Dashed ellipses indicate hierarchical clustering results at $60 \%$ similarity. Overlain vectors indicate the most important prey items leading to trophic guild separation, and prey item names are shown in blue, italic text.

$(\mathrm{J})$ indicates juvenile tuna species groups groups representing the top of the CNP pelagic ecosystem are nicely clustered according to relative depths of forage, as well as by average diet composition. For example, large billfishes ('striped marlin', 'blue marlin', 'other billfishes') cluster with 'mahimahi' Coryphaena hippurus with increasingly positive PC2 scores, denoted by high consumption of 'small epipelagic fishes' (e.g. molids, flying fish). Commercially important billfishes and mahi-mahi have broadly known feeding habits focused on smaller epipelagic fishes, mollusks, and crustaceans (e.g. Gibbs \& Collette 1959, Brock 1984, Moteki et al. 2001, Olson \& Galvan-Magana 2002). Another shallow-foraging cluster of fishes are the juvenile tunas (albacore, yellowfin, and skipjack), which have high PC2 and low PC1 scores to indicate the dietary importance of 'other crustaceans' such as stomatopods and amphipods, and 'mesopelagic zooplankton' such as euphausiids. In contrast, spread across PC1, but all with negative PC2 scores, are deepdiving and presumably deep-foraging pelagic fishes (e.g. 'broadbill swordfish', 'snake mackerel \& escolars', 'opah' Lampris guttatus, 'bigeye tuna' Thunnus obesus) along with 'toothed whales' (Fig. 2B). These deep-foraging predators all consume substantial amounts of large, vertically migrating onychoteuthid and ommastrephid squids (indicated by negative PC2 scores), but also feed on varying amounts of other mollusks and large pelagic fishes, as well as micronekton crustaceans such as amphipods (King \& Ikehara 1956, Moteki et al. 2001, Barlow et al. 2008, Watanabe et al. 2009, Choy et al. 2013). At the $60 \%$ similarity level, 'sea birds' cluster with 'albacore tuna' and 'skipjack tuna', all of which are known to form subsurface feeding aggregations (Hebshi et al. 2008). The anomalously feeding planktivorous animals are the 'sea turtle' and 'baleen whale' groups, which cluster 
near to one another in PCA space, but do not cluster closely with other predators. Thus, the PCA results from both the micronekton and top predator functional groups align well with known dietary expectations reported in the literature, and directly guide interpretation of ecosystem model perturbation scenarios according to parameterized diet.

\section{Micronekton functional group contributions to biomass and energy flow}

The trophic levels of the 9 micronekton functional groups were estimated from the Ecopath model based on their diets. The micronekton groups encompassed 2 trophic levels, ranging from 2.11 for 'filterfeeding gelatinous' organisms to 4.07 for 'epipelagic mollusks' and 'carnivorous micronekton fishes', with most groups estimated at approximately trophic level 3 (Table 1). Relative productivity, measured as the ratio of production to biomass (P:B), ranged from 1.5 for 'bathypelagic fishes' to 8 for the 'other crustaceans' group. The P:B for 'other crustaceans' is well above values of all other micronekton groups and explains why that group accounts for $29 \%$ of the micronekton production, more than double that of any other micronekton group, even though it represents only $13 \%$ of total micronekton biomass (Table 3). The 3 fish groups together represent approximately $54 \%$ of micronekton biomass but only $28 \%$ of micronekton production. The pattern is opposite for the 2 crustacean groups that together represent only $24 \%$ of biomass but $44 \%$ of production (Table 3). The 2 remaining micronekton categories, gelatinous organisms and mollusks, account for 12 and $11 \%$, respectively, of total micronekton biomass and 17 and $11 \%$ of total micronekton production. Three functional micronekton groups, 'other crus- taceans', 'epipelagic mollusks', and 'mesopelagic mollusks' figure prominently in the diets of higher trophic organisms. 'Other crustaceans' account for 20 to $40 \%$ of the diet of juvenile tuna while the $2 \mathrm{~mol}-$ lusks groups account for 10 to $60 \%$ of the diets of apex species including marlins, swordfish, and toothed whales.

\section{Micronekton perturbation scenarios in Ecosim}

Food-web-wide responses (measured as percent change in biomass per group from initialized model biomass) are visualized as heat maps in Fig. 3. We focus separately on visualizing the responses to the micronekton perturbation scenarios within the middle of the food web (Fig. 3A) and at the top of the food web (Fig. 3B) to provide individual group-level context to the pooled trophic level biomass results shown in Fig. 4. Biomass impacts to the top of the food web were highly variable in response to independently reducing the biomass of each of the 9 micronekton groups. The most direct negative changes in the species groups with the highest trophic levels (>4.5) occurred in response to $30 \%$ reductions in 'other crustaceans' followed by 'epipelagic mollusks' (Fig. 4). Predator groups with a trophic level between 4.0 and 4.5 appeared to be the least affected by reductions in micronekton biomass (Fig. 4). The micronekton groups with an overall positive effect on the highlevel trophic species groups were 'predatory gelatinous' and 'zooplanktivorous micronekton fishes', with the latter just barely resulting in positive increases in apex species biomass.

As parameterized by the Ecopath model, the 9 micronekton groups all have finite shared prey resources (meso- and microzooplankton, some of the phytoplankton groups; see diet matrix, Table S2 in the

Table 3. Comparison of modeled bioenergetic parameters for the 9 micronekton functional groups. Percent biomass, production, and consumption are computed for the 9 mid-trophic micronekton groups only. Production:biomass ratios $_{\left(\mathrm{P}: \mathrm{B}_{i} \mathrm{yr}^{-1}\right)} \mathrm{are}^{-}$ also provided

\begin{tabular}{|c|c|c|c|c|}
\hline Micronekton functional group & $\begin{array}{c}\text { Micronekton } \\
\text { biomass }(\mathrm{B}, \%)\end{array}$ & $\begin{array}{c}\text { Micronekton } \\
\text { production }(\mathrm{P}, \%)\end{array}$ & $\begin{array}{c}\text { Micronekton } \\
\text { consumption }(\mathrm{Q}, \%)\end{array}$ & $\mathrm{P}: \mathrm{B}$ \\
\hline Zooplanktivorous micronekton fishes & 24.8 & 14.6 & 15.2 & 2.10 \\
\hline Carnivorous micronekton fishes & 16.7 & 8.0 & 7.7 & 1.70 \\
\hline Decapod crustaceans & 10.7 & 14.4 & 20.4 & 4.80 \\
\hline Other crustaceans & 13.0 & 29.2 & 24.9 & 8.00 \\
\hline Predatory gelatinous & 8.0 & 11.2 & 15.3 & 5.01 \\
\hline Filter-feeding gelatinous & 3.9 & 5.9 & 6.0 & 5.40 \\
\hline Epipelagic mollusks & 3.8 & 3.8 & 2.9 & 3.50 \\
\hline Mesopelagic mollusks & 6.8 & 7.7 & 5.2 & 4.00 \\
\hline Bathypelagic fishes & 12.4 & 5.2 & 2.3 & 1.50 \\
\hline
\end{tabular}


A) Micronekton functional group responses to simulated micronekton changes

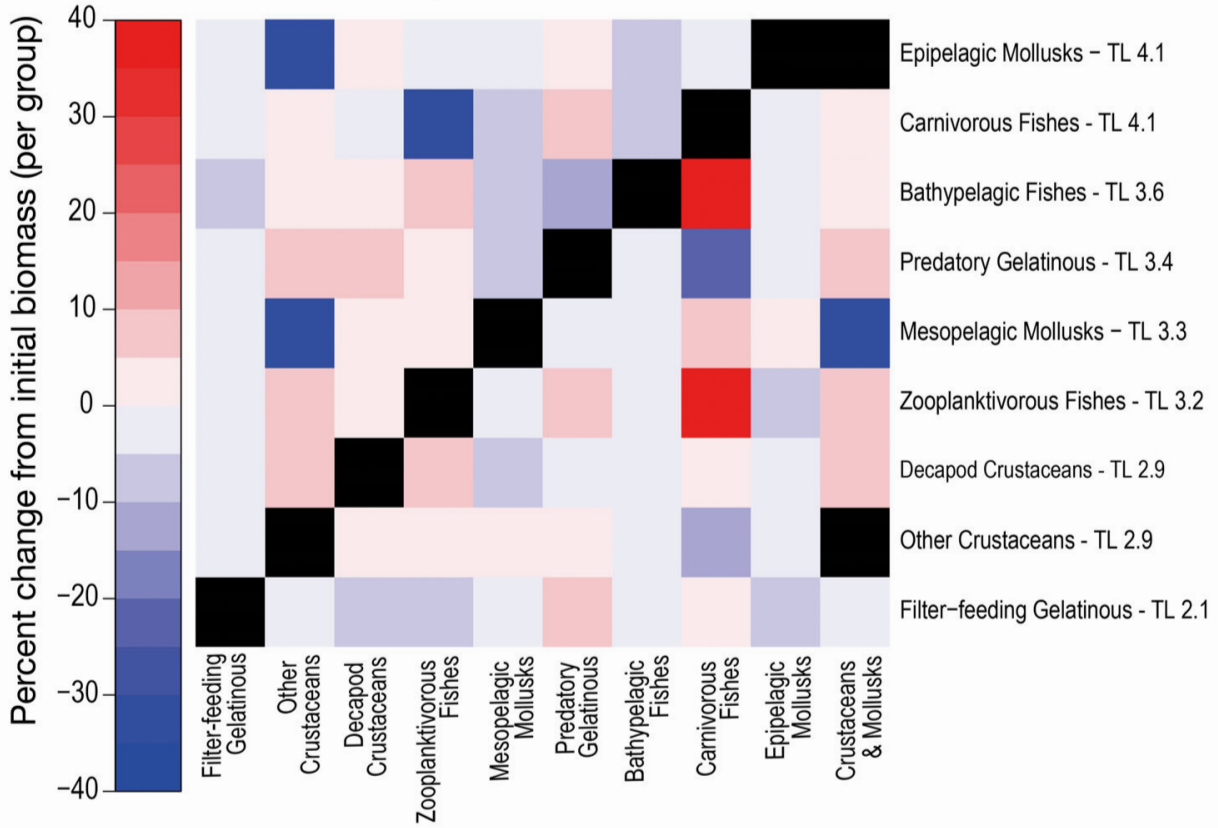

B) Predator functional group responses to simulated micronekton changes

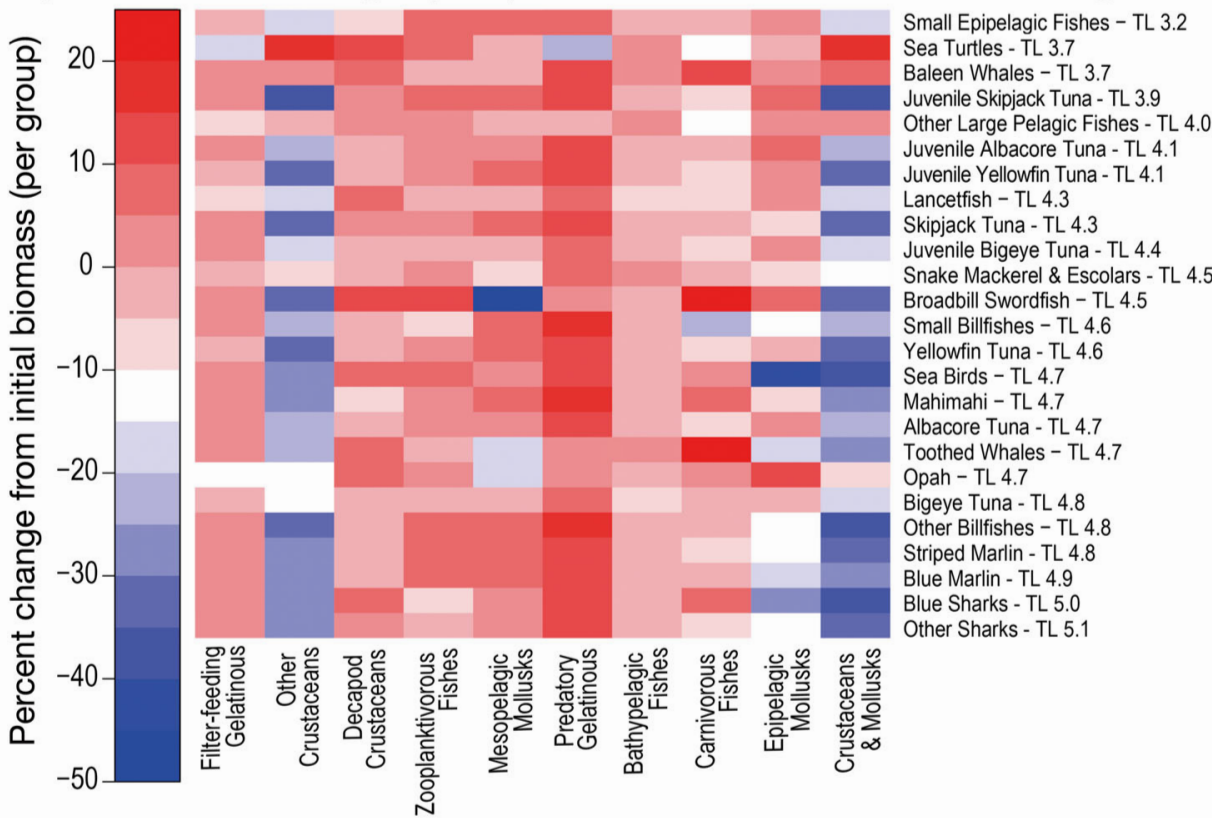

Fig. 3. Heat map diagrams illustrating how each functional group (rows) changes in response to independent $30 \%$ reductions in the biomass of each of the 9 micronekton groups (columns), and to the 'crustaceans and mollusks' scenario (where 'other crustaceans' and 'epipelagic mollusks' are both simultaneously reduced by $30 \%$ ). Separate heat maps are shown for (A) the middle of the food web (micronekton groups) and (B) the top of the food web. Warmer colors indicate positive responses, while cooler colors indicate negative responses (as percent change from initial bio mass). TL: trophic level

Supplement). Additionally, some of the larger, higher trophic level micronekton groups (e.g. 'epipelagic mollusks' and 'bathypelagic fishes') also prey heavily upon the smaller, lower trophic level micronekton groups (e.g. 'decapod crustaceans', 'zooplanktiverous micronekton fishes'). An understanding of between-group micronekton dynamics can explain the variable responses within the middle of the food web when the biomass of each micronekton group is independently decreased (Fig. 3A). For example, when the biomass of the 'other crustaceans' group is reduced by $30 \%$ in Ecosim there are 3 different responses within the micronekton community (Fig. 3A). First, large squids, the primary mid-trophic predators of this group, decrease $(\sim 26 \%)$ while their trophic competitors ('decapod crustaceans', 'zooplanktivorous micronekton fishes', and 'predatory gelatinous' animals) secondarily increase in response by 8 to $12 \%$. Finally, other groups lacking prominent trophic connections to the 'other crustaceans' show little to no change in biomass (e.g. 'filter feeding gelatinous').

At the top of the food web (except for 'sea turtles', 'baleen whales', and 'other large pelagic fishes'), the largest, across-theboard negative biomass changes are seen in response to a $30 \%$ decrease in 'other crustaceans' (Fig. 3B). Aside from 'opah' and 'snake mackerel and escolars', all predator groups decline by $>14 \%$ and up to $36 \%$ for 'juvenile skipjack tunas', indicating that 'other crustaceans' are the most critical pathway bridging the top and bottom of the CNP pelagic food web. This functional group comprises 20 to $40 \%$ of the diets of juvenile tunas, which are then directly and strongly linked to apex predators such as large billfish and sharks. With a P:B value of 8 , a $30 \%$ reduction in biomass of this group is highly amplified across multiple food web pathways (Table 3 ).

A $30 \%$ reduction in the biomass of 'epipelagic mollusks' and 'mesopelagic mollusks' elicited the next 2 most negative responses to the top of the 


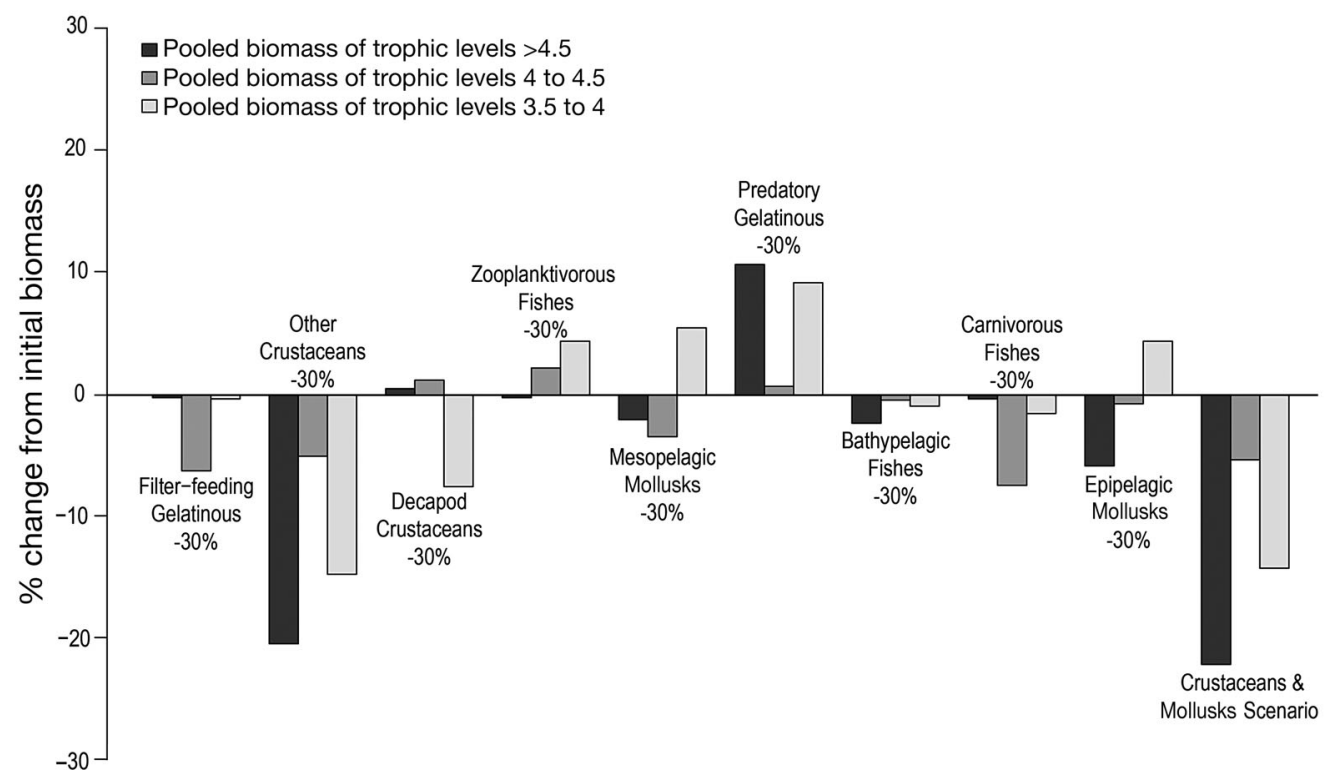

Fig. 4. Grouped bar plot showing the percent change for pooled fractional trophic levels from initial biomass levels, in response to independent $30 \%$ biomass reductions in each of the 9 micronekton functional groups. Biomass changes to the micronekton groups that fall within the pooled fractional trophic level ranges represented here are not included in final tabulations. At the far right are predicted changes to pooled fractional trophic levels in response to the 'crustaceans and mollusks' scenario, where the biomass of 'other crustaceans' and of 'epipelagic mollusks' are simultaneously reduced by $30 \%$ in Ecosim

food web. For the 'mesopelagic mollusks' this was especially true for the 'broadbill swordfish' Xiphias gladius, 'opah', and 'toothed whales'. All 3 of these predators feed heavily on 'mesopelagic mollusks' (Barlow et al. 2008, Watanabe et al. 2009, Choy et al. 2013), indicating that projected declines are direct food web responses to changes in one of their primary prey items. Additional support for this type of direct food web response occurred when biomass reductions in 'epipelagic mollusks' led to large declines in 'sea birds' $(40 \%)$, 'blue sharks' $(27 \%)$, 'toothed whales' $(16 \%)$, and 'blue marlins' $(15 \%)$. Declines in 'predatory gelatinous' organisms also elicited a strong decline $(21 \%)$ in sea turtles. Reductions in biomasses of many of the other micronekton groups resulted in biomass increases at the highest trophic levels. These micronekton groups are generally not highly important prey items of top trophic level species groups, so a reduction in their biomass allows energy to flow through the more efficient pathways of 'other crustaceans' and 'mesopelagic mollusks' (Fig. 5). The specific importance of the 'other crustaceans' and 'epipelagic mollusks' micronekton groups to the top of the food web is highlighted in the 'crustaceans and mollusks' scenario, which resulted in substantial declines in almost all top predator groups (Fig. 3B).

\section{DISCUSSION}

Our Ecopath model is, to date, the most comprehensive attempt to examine energy flows within the CNP pelagic ecosystem by focusing on the relative trophic importance of key micronekton functional groups comprising the middle of the food web. We attempted to more comprehensively partition and parameterize fish, crustacean, mollusk, and gelatinous micronekton taxa into our ecosystem model, as has been done previously but sparingly with other ecosystem models (Lehodey et al. 2010). A key result was that crustaceans represented $24 \%$ of micronekton biomass but generated $44 \%$ of the overall (9 micronekton functional groups) production. In particular, 'other crustaceans' (e.g. mysids, amphipods, isopods, etc.) represented only $13 \%$ of the micronekton biomass but accounted for $29 \%$ of total micronekton production. By simulating the independent removal of each micronekton group, our results showed the direct trophic importance of micronekton crustaceans and epipelagic mollusks to predatory fishes and marine mammals at the top of the CNP pelagic food web. Simulated micronekton biomass reductions resulted in varying degrees of top predator declines. In some instances these changes were substantial, indicating that trophic flow in this ecosystem can be strongly controlled by dynamics of 


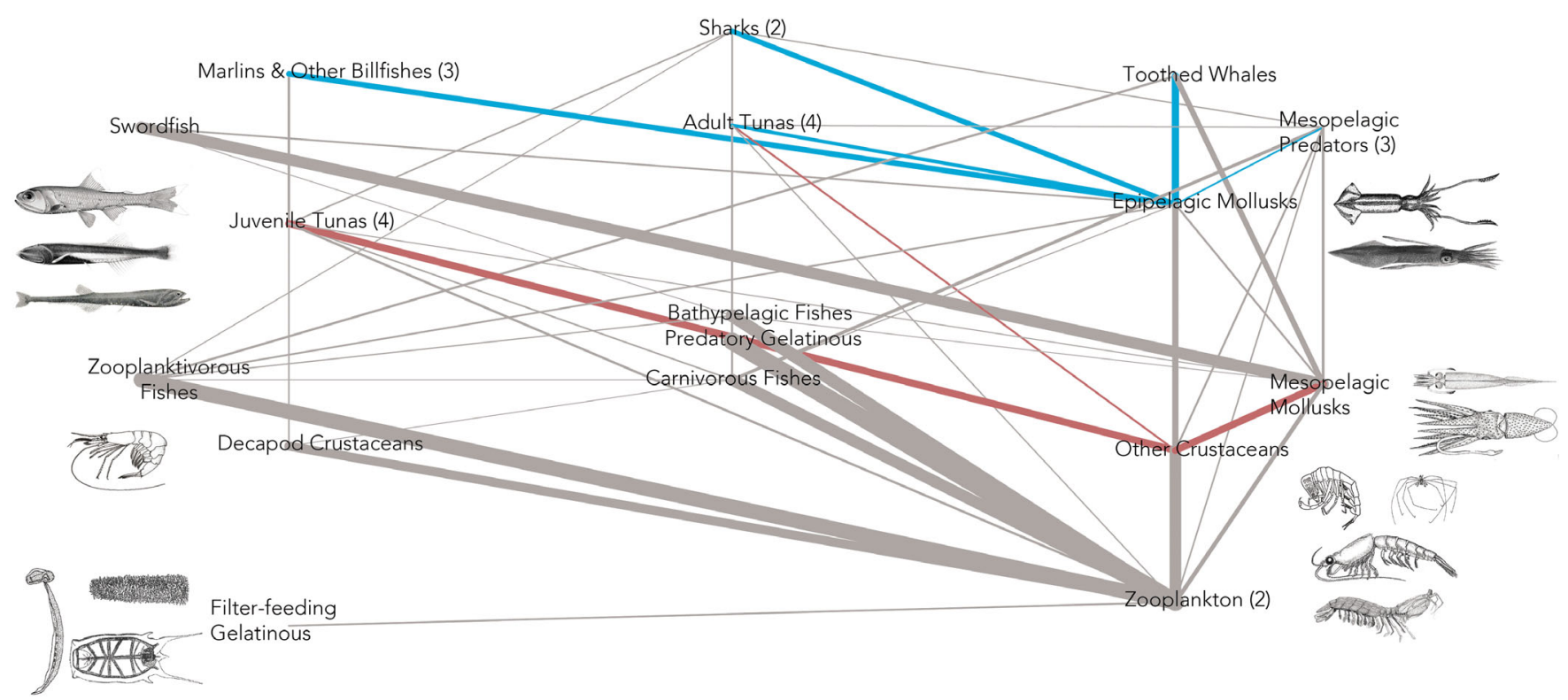

Fig. 5. Simplified food web diagram showing the energy flow through key micronekton and top predator functional groups. Diet proportions $5 \%$ or greater (from the balanced diet matrix) are shown between groups, where the thickness of the lines is scaled to parameterized diet proportions. Numbers in parentheses next to group names indicate the number of pooled functional groups within that group, and diet fractions are averaged for included groups. Colored lines highlight the energy pathways of 'other crustaceans' (red) and 'epipelagic mollusks' (blue) through the food web

select mid-trophic micronekton groups. Predicted declines in total biomass levels at the top of the food web were quite substantial in response to simulated reductions in 'other crustaceans', 'epipelagic mollusks', and 'mesopelagic mollusks' (Figs. 3 \& 4B). Reductions in other micronekton groups showed little impact or, in some cases, resulted in increases in biomass at top trophic levels. These results suggest that the biomass at the top trophic levels is sensitive to the composition of micronekton functional groups, particularly the biomass proportions of mollusks and crustaceans relative to other groups. The magnitude of these top predator declines was equal to or greater than those predicted by Howell et al. (2013) in response to declines in phytoplankton biomass and increased fishing effort.

Ecosystem models have previously been developed for different sectors of the Pacific Ocean, primarily to anticipate ecosystem impacts resulting from changes in commercial fishing pressure (e.g. Cox et al. 2002a, Kitchell et al. 2002, Essington 2006), and/or climate variability and change (e.g. Watters et al. 2003, Griffiths et al. 2010, Howell et al. 2013). To fully understand these ecosystems and more meaningfully inform fishery managers of activities utilizing and impacting these systems, it is important to discern energy flows through mid-trophic groups, in addition to food web impacts of fishing and climate change. Earlier ecosystem models of the Pacific Ocean para- meterized mid-trophic forage groups as lumped cephalopod, fish (epipelagic and mesopelagic together, in some cases), and zooplankton (microzooplankton and mesozooplankton) groups. Later studies highlighted the importance of some of these mid-trophic groups in funneling energy to higher trophic levels. For example, in the eastern tropical Pacific ecosystem, Watters et al. (2003) identified the 'axis of the Auxis' and the 'axis of the squid' as important midtrophic pathways for translating climate induced bottom-up changes (e.g. El Niño Southern Oscillation, ENSO) to the top of the food web. Additionally, Griffiths et al. (2010) demonstrated that mesopelagic fish such as myctophids and cephalopods with high biomass and high production and consumption rates exert strong 'wasp-waist' control within the pelagic ecosystem off eastern Australia.

The oceanographic setting of the CNP ecosystem model is distinct from those in the eastern tropical Pacific, southeastern Australia, and the California Current. The California Current, for example, is a highly productive ecosystem with wind-driven upwelling that delivers high levels of nutrients to surface waters. Kaplan et al. (2013b) demonstrated that the specific removal of key forage species such as euphausiids, sardines, and anchovies had substantial impacts on top predator biomass in the California Current. While interannual cycles of the Pacific Decadal Oscillation and ENSO have a demonstrated 
influence on the dominance of different forage species in the California Current (Barber \& Chavez 1983, Chavez et al. 2003, Koslow et al. 2011), the CNP pelagic ecosystem described here generally presents dynamics more similar to those reported from southeastern Australia. However, the CNP pelagic ecosystem does not appear to exhibit the 'wasp-waist' control described by Griffiths et al. (2010), with midtrophic biomass spread across multiple species and functional groups of shared but varying trophic importance to the top of the food web. The idea of ecosystem resilience due to diverse species assemblages within the CNP is supported by earlier ecosystem modeling efforts (Kitchell et al. 1999, Cox et al. 2002a) and independent lines of study. For example, Choy et al. (2015) reported a high degree of overlap in the trophic positions of 10 species of top predator tunas, billfishes, and mesopredators included in this ecosystem model. Redundancy in trophic positions was attributed to niche partitioning in diet and vertical habitat preferences, and these ecological niches are represented here. PCA results from the present study showed important trophic differences in the way mesopredators and top predators of the CNP pelagic ecosystem would respond to changes in micronekton composition based on distinct dietary preferences (Fig. 2).

By independently simulating micronekton reductions with targeted scenarios we were able to track food web responses in primary prey resources (zooplankton) and key predator groups (e.g. mesopredators, tunas, billfishes, sharks, and toothed whales), highlighting the relative importance of diverse micronekton groups in structuring energy flow from primary and secondary producers through to apex species. The most direct negative changes in apex predator species occurred in response to declines in 'other crustaceans' (Fig. 4B), which are not necessarily primary prey items for these apex species, but function as an important food web node with strong trophic connections to other micronekton groups ('epipelagic mollusks' and 'mesopelagic mollusks') and intermediate predators (juvenile tunas) (Fig. 5). Apex predators declined in response to reductions in intermediate trophic groups who prey directly on micronekton crustaceans (Fig. 4). These important food web pathways are underlined in the 'crustaceans and mollusks' scenario, wherein the simultaneous reduction of the 'other crustaceans' and 'epipelagic mollusks' groups caused significant declines in the highest trophic levels (Fig. 3). Other micronekton, such as the 2 gelatinous groups, function more as trophic shunts in overall food web energy flow. Gelatinous micronekton taxa are not dominant in the diets of apex predators, but can consume large amounts of zooplankton and ultimately reduce available resources for other micronekton that are preyed upon more heavily by intermediate and apex predators. The role of gelatinous taxa as trophic 'dead ends' has also been reported from the Northern California Current (Brodeur et al. 2008, Ruzicka et al. 2012). However, it is possible that their direct importance as prey based on stomach content analyses may be underestimated due to rapid digestion (Choy et al. 2013).

The application of the ecological modeling software suite Ecopath with Ecosim to gain greater understanding of the importance of mid-trophic micronekton groups to top predator production is appealing and practical, as demonstrated by a number of previous studies (Field et al. 2010, Griffiths et al. 2010, Ruzicka et al. 2012, Kaplan et al. 2013b). However, some of the approach's limitations and assumptions warrant studies focusing on ways to comprehensively evaluate and improve current findings.

Firstly, much of the foundation of an Ecopath model lies in its diet matrix describing the predatorprey interactions between different food web components. While based on empirical data, availability and sample size of studies describing feeding habits of species included within the diet matrix are likely to be disproportionally skewed toward commercially important species (e.g. tuna and billfish species), declining in scope as one moves down the food web. Inferring diet in pelagic animals from stomach content analysis is widely acknowledged as being limited by generally small sample sizes from difficult-toobtain specimens that may miss seasonal, spatial, or even ontogenetic shifts in diet (Allain et al. 2007, Kaplan et al. 2013b). Future work should seek to evaluate this type of underlying uncertainty in the parameterized diets, including how diet might change with animal size or prey availability, and how this might influence overall energy flow within pelagic ecosystems. Secondly, through the synthesis of existing studies and data, as well as communication with relevant experts, this exercise underlined the lack of a strong empirical foundation for mid-trophic micronekton groups (Buckley \& Buckley 2010, Handegard et al. 2013). Given their importance in the functioning of pelagic systems, and to better understand and manage future impacts to these very systems, targeted efforts to obtain empirical biological data for these groups should be encouraged and supported. Finally, Ecopath models do not consider differences in the energy content of prey in contributing to overall energy flow through the food web. Diverse micro- 
nekton taxa can differ substantially in potential energy content (on a per gram basis). For example, lipid contents of myctophid fishes (the primary species component of our 'zooplanktivorous fishes' group) can be up to an order of magnitude greater than those of mature epipelagic fish and squid prey (Childress et al. 1990, Van Pelt et al. 1997). Thus, lower levels of consumption of high energy density prey items will contribute disproportionately more to overall energy flow and declines in these species are likely to inordinately impact the fitness of their predators. This should be considered when interpreting biomass changes based on parameterized diet compositions in this study and others utilizing Ecopath.

While all modeling approaches are accompanied by uncertainty and caveats, our results aim to augment existing ecological findings and provide a baseline quantification of the ecological significance of mid-trophic micronekton communities to overall pelagic ecosystem structure and energy flow. Future studies might consider expanding the use of our midtrophic group reduction scenarios, building in stronger empirical bases for model parameterization, and exploring the potential impacts of climate change on altering the overall flow and partitioning of energy in pelagic systems. The continued refinement and expansion of pelagic ecosystem models ultimately increases their utility and flexibility toward future applications and improvements of ecosystem-based management efforts for finite and dynamic pelagic resources, especially in the advent of climate change.

Acknowledgements. This work was funded by the Joint Institute of Marine and Atmospheric Research (JIMAR) via Cooperative Agreement NA09OAR4320075 between JIMAR and the National Oceanic and Atmospheric Administration (NOAA). C.A.C. was primarily supported by JIMAR, as well as by the David and Lucile Packard Foundation. The views expressed herein are those of the authors and do not necessarily reflect the views of NOAA or any of its subdivisions. The authors thank Evan Howell and Brian Langseth for invaluable assistance with model parameters, balancing, and general software implementation. James Ruzicka, John Field, Amanda Dillon, and Chiara Piroddi provided helpful Ecopath advice. Michael Seki, Jeffrey Drazen, T. Todd Jones, Karen Arthur, Jennifer Purcell, Cathy Lucas, Irene Kelly, Dawn Golden, and Erin Oleson all provided expert advice for biological input parameters. ESM2.1 data were provided by John Dunne. Our manuscript was substantially improved by the contributions and input of 3 anonymous reviewers. This is SOEST contribution number 9615.

\section{LITERATURE CITED}

Allain V, Nicol S, Essington TE, Okey T, Olson RJ, Kirby D (2007) Ecopath model of the Western and Central Pacific
Ocean warm pool pelagic ecosystem. Ocean Fisheries Programme Secretariat of the Pacific Community Noumea, WCPFC-SC1EBWP1. https://www.wcpfc.int/ system/files/SC1_EB_WP_10.pdf

Alldredge AL, Madin LP (1982) Pelagic tunicates: unique herbivores in the marine plankton. Bioscience 32: 655-663

Barber RT, Chavez FP (1983) Biological consequences of El Niño. Science 222:1203-1210

> Barlow J, Kahru M, Mitchell BG (2008) Cetacean biomass, prey consumption, and primary production requirements in the California Current ecosystem. Mar Ecol Prog Ser 371:285-295

Bigelow KA, Hampton J, Miyabe N (2002) Application of a habitat-based model to estimate effective longline fishing effort and relative abundance of Pacific bigeye tuna (Thunnus obesus). Fish Oceanogr 11:143-155

Brock RE (1984) A contribution to the trophic biology of the blue marlin (Makaira nigricans Lacépède, 1802) in Hawaii. Pac Sci 38:141-149

Brodeur R, Yamamura O (eds) (2005) Micronekton of the North Pacific. PICES Sci Rep 30:1-115

Brodeur RD, Suchman CL, Reese DC, Miller TW, Daly EA (2008) Spatial overlap and trophic interactions between pelagic fish and large jellyfish in the northern California Current. Mar Biol 154:649-659

Brodziak J, Link J (2002) Ecosystem-based fishery management: What is it and how can we do it? Bull Mar Sci 70: 589-611

Buckley LJ, Buckley LB (2010) Toward linking ocean models to fish population dynamics. Prog Oceanogr 84:85-88

Chavez FP, Ryan J, Lluch-Cota SE, Niquen M (2003) From anchovies to sardines and back: multidecadal change in the Pacific Ocean. Science 299:217-221

Childress JJ, Taylor SM, Cailliet GM, Price MH (1980) Patterns of growth, energy utilization and reproduction in some meso- and bathypelagic fishes off southern California. Mar Biol 61:27-40

Childress JJ, Price MH, Favuzzi J, Cowles D (1990) Chemical composition of midwater fishes as a function of depth of occurrence off the Hawaiian Islands: food availability as a selective factor? Mar Biol 105:235-246

> Choy CA, Portner E, Iwane M, Drazen JC (2013) Diets of five important predatory mesopelagic fishes of the central North Pacific. Mar Ecol Prog Ser 492:169-184

- Choy CA, Popp BN, Hannides CCS, Drazen JC (2015) Trophic structure and food resources of epipelagic and mesopelagic fishes in the North Pacific Subtropical Gyre ecosystem inferred from nitrogen isotopic compositions: trophic structure of pelagic fishes. Limnol Oceanogr 60: 1156-1171

Christensen V, Walters CJ (2004) Ecopath with Ecosim: methods, capabilities and limitations. Ecol Modell 172: 109-139

Christensen V, Walters C, Pauly D, Forrest R (2008) Ecopath with Ecosim version 6 user guide. University of British Columbia, Vancouver

> Clark WG (2002) $F_{35 \%}$ revisited ten years later. N Am J Fish Manage 22:251-257

Clarke TA (1973) Some aspects of the ecology of lanternfishes (Myctophidae) in the Pacific Ocean near Hawaii. Fish Bull 71:401-434

Clarke TA (1974) Some aspects of the ecology of stomiatoid fishes in the Pacific Ocean near Hawaii. Fish Bull 72: $337-351$ 
Clarke TA (1978) Diel feeding patterns of 16 species of mesopelagic fishes from Hawaiian waters. Fish Bull 76: 495-513

Clarke KR, Gorley RN (2006) PRIMER V6: user manual and tutorial. Primer-E, Plymouth, UK

Clarke TA, Wagner PJ (1976) Vertical distribution and other aspects of the ecology of certain mesopelagic fishes taken near Hawaii. Fish Bull 74:635-647

Colléter M, Valls A, Guitton J, Gascuel D, Pauly D, Christensen V (2015) Global overview of the applications of the Ecopath with Ecosim modeling approach using the EcoBase models repository. Ecol Modell 302:42-53

Corno G, Karl DM, Church MJ, Letelier RM, Lukas R, Bidigare RR, Abbott MR (2007) Impact of climate forcing on ecosystem processes in the North Pacific Subtropical Gyre. J Geophys Res Oceans 112:C04021, doi:10.1029/ 2006JC003730

> Cox SP, Essington TE, Kitchell JF, Martell SJ, Walters CJ, Boggs C, Kaplan I (2002a) Reconstructing ecosystem dynamics in the central Pacific Ocean, 1952-1998. II. A preliminary assessment of the trophic impacts of fishing and effects on tuna dynamics. Can J Fish Aquat Sci 59: 1736-1747

Cox SP, Martell SJ, Walters CJ, Essington TE, Kitchell JF, Boggs C, Kaplan I (2002b) Reconstructing ecosystem dynamics in the central Pacific Ocean, 1952-1998. I. Estimating population biomass and recruitment of tunas and billfishes. Can J Fish Aquat Sci 59:1724-1735

Darwall WRT, Allison EH, Turner GF, Irvine K (2010) Lake of flies, or lake of fish? A trophic model of Lake Malawi. Ecol Modell 221:713-727

> Davison PC, Checkley DM Jr, Koslow JA, Barlow J (2013) Carbon export mediated by mesopelagic fishes in the northeast Pacific Ocean. Prog Oceanogr 116:14-30

> Delworth TL, Broccoli AJ, Rosati A, Stouffer RJ and others (2006) GFDL's CM2 global coupled climate models. Part I: formulation and simulation characteristics. J Clim 19: 643-674

Doney SC, Ruckelshaus M, Emmett Duffy J, Barry JP and others (2012) Climate change impacts on marine ecosystems. Annu Rev Mar Sci 4:11-37

> Drazen JC, De Forest LG, Domokos R (2011) Micronekton abundance and biomass in Hawaiian waters as influenced by seamounts, eddies, and the moon. Deep Sea Res Part I Oceanogr Res Pap 58:557-566

Dunne JP, Armstrong RA, Gnanadesikan A, Sarmiento JL (2005) Empirical and mechanistic models for the particle export ratio. Global Biogeochem Cycles 19:GB4026, doi: 10.1029/2004GB002390

Essington TE (2006) Pelagic ecosystem response to a century of commercial fishing and whaling. In: Estes JA, DeMaster DP, Doak DF, Williams TM, Brownwell RL (eds) Whales, whaling, and ocean ecosystems. University of California Press, Berkeley, CA, p 38-49

Fabry VJ, Seibel BA, Feely RA, Orr JC (2008) Impacts of ocean acidification on marine fauna and ecosystem processes. ICES J Mar Sci 65:414-432

Field JC, MacCall AD, Bradley RW, Sydeman WJ (2010) Estimating the impacts of fishing on dependent predators: a case study in the California Current. Ecol Appl 20: 2223-2236

Froese R, Pauly D (2015) FishBase. www.fishbase.org (accessed June 2015)

Gibbs RH Jr, Collette BB (1959) On the identification, distribution, and biology of the dolphins, Coryphaena hippu- rus and C. equiselis. Bull Mar Sci 9:117-152

Gjosaeter J, Kawaguchi K (1980) A review of the world resources of mesopelagic fish. Food and Agriculture Organization of the United Nations, Rome

> Gnanadesikan A, Dixon KW, Griffies SM, Balaji V and others (2006) GFDL's CM2 Global Coupled Climate Models. Part II: The Baseline Ocean Simulation. J Clim 19:675-697

> Gregg WW, Rousseaux CS (2014) Decadal trends in global pelagic ocean chlorophyll: a new assessment integrating multiple satellites, in situ data, and models. J Geophys Res Oceans 119:5921-5933

> Griffiths SP, Young JW, Lansdell MJ, Campbell RA and others (2010) Ecological effects of longline fishing and climate change on the pelagic ecosystem off eastern Australia. Rev Fish Biol Fish 20:239-272

Haddock SHD (2004) A golden age of gelata: past and future research on planktonic ctenophores and cnidarians. Hydrobiologia 530:549-556

Handegard NO, du Buisson L, Brehmer P, Chalmers SJ and others (2013) Towards an acoustic-based coupled observation and modelling system for monitoring and predicting ecosystem dynamics of the open ocean. Fish Fish 14: $605-615$

Harrison CS, Seki MP (1987) Trophic relationships among tropical seabirds at the Hawaiian Islands. In: Croxall JP (ed) Seabirds: feeding ecology and role in marine ecosystems. Cambridge University Press, Cambridge, p 305-326

> He X, Bigelow KA, Boggs CH (1997) Cluster analysis of longline sets and fishing strategies within the Hawaiibased fishery. Fish Res 31:147-158

> Hebshi AJ, Duffy DC, Hyrenbach KD (2008) Associations between seabirds and subsurface predators around Oahu, Hawaii. Aquat Biol 19:89-98

Heymans JJ, Coll M, Link JS, Mackinson S, Steenbeek J, Walters C, Christensen V (2016) Best practice in Ecopath with Ecosim food-web models for ecosystem-based management. Ecol Modell (in press)

> Hopkins TL, Gartner JV (1992) Resource-partitioning and predation impact of a low-latitude myctophid community. Mar Biol 114:185-197

- Hopkins TL, Flock ME, Gartner JV, Torres JJ (1994) Structure and trophic ecology of a low latitude midwater decapod and mysid assemblage. Mar Ecol Prog Ser 109:143

Hoving HJT, Perez JA, Bolstad KS, Braid HE and others (2014) The study of deep-sea cephalopods. Adv Mar Biol $67: 235-359$

Howell EA, Wabnitz CCC, Dunne JP, Polovina JJ (2013) Climate-induced primary productivity change and fishing impacts on the Central North Pacific ecosystem and Hawaii-based pelagic longline fishery. Clim Change 119:79-93

Irigoien X, Klevjer TA, Røstad A, Martinez U and others (2014) Large mesopelagic fishes biomass and trophic efficiency in the open ocean. Nat Commun 5:3271

Kaartvedt S, Staby A, Aksnes DL (2012) Efficient trawl avoidance by mesopelagic fishes causes large underestimation of their biomass. Mar Ecol Prog Ser 456:1-6

Kaplan MB, Mooney TA, McCorkle DC, Cohen AL (2013a) Adverse effects of ocean acidification on early development of squid (Doryteuthis pealeii). PLoS ONE 8:e63714

Kaplan IC, Brown CJ, Fulton EA, Gray IA, Field JC, Smith ADM (2013b) Impacts of depleting forage species in the California Current. Environ Conserv 40:380-393

Karl DM (1999) A sea of change: biogeochemical variability in the North Pacific Subtropical Gyre. Ecosystems 2:181-214 
Karl DM, Bidigare RR, Letelier RM (2001) Long-term changes in plankton community structure and productivity in the North Pacific Subtropical Gyre: the domain shift hypothesis. Deep-Sea Res II 48:1449-1470

King JE, Ikehara II (1956) Comparative study of food of bigeye and yellowfin tuna in the central Pacific. Fish Bull 57: 61-81

- Kitchell JF, Boggs CH, He X, Walters CJ (1999) Keystone predators in the central Pacific. Ecosyst Approaches Fish Manag 16:665-683

Kitchell JF, Essington TE, Boggs CH, Schindler DE, Walters CJ (2002) The role of sharks and longline fisheries in a pelagic ecosystem of the Central Pacific. Ecosystems 5: 202-216

> Koslow JA, Kloser RJ, Williams A (1997) Pelagic biomass and community structure over the mid-continental slope off southeastern Australia based upon acoustic and midwater trawl sampling. Mar Ecol Prog Ser 146:21-35

Koslow JA, Goericke R, Lara-Lopez A, Watson W (2011) Impact of declining intermediate-water oxygen on deepwater fishes in the California Current. Mar Ecol Prog Ser 436:207-218

> Lehodey P, Murtugudde R, Senina I (2010) Bridging the gap from ocean models to population dynamics of large marine predators: a model of mid-trophic functional groups. Prog Oceanogr 84:69-84

> Link JS (2010) Adding rigor to ecological network models by evaluating a set of pre-balance diagnostics: a plea for PREBAL. Ecol Modell 221:1580-1591

> Lucas CH, Jones DOB, Hollyhead CJ, Condon RH and others (2014) Gelatinous zooplankton biomass in the global oceans: geographic variation and environmental drivers. Glob Ecol Biogeogr 23:701-714

Mackinson S, Daskalov G, Heymans JJ, Neira S and others (2009) Which forcing factors fit? Using ecosystem models to investigate the relative influence of fishing and changes in primary productivity on the dynamics of marine ecosystems. Ecol Model 220:2972-2987

Mauchline J, Gordon JDM (1986) Foraging strategies of deep-sea fish. Mar Ecol Prog Ser 27:227-238

Maynard SD, Riggs FV, Walters J (1975) Mesopelagic micronekton in Hawaiian waters: faunal composition, standing stock, and diel vertical migration. Fish Bull 73:726-736

Moteki M, Arai M, Tsuchiya K, Okamoto H (2001) Composition of piscine prey in the diet of large pelagic fish in the eastern tropical Pacific Ocean. Fish Sci 67:1063-1074

Mundy BC (2005) Checklist of the fishes of the Hawaiian Archipelago. Bishop Museum Press, Honolulu, HI

Olson RJ, Galvan-Magana F (2002) Food habits and consumption rates of common dolphinfish (Coryphaena hippurus) in the eastern Pacific Ocean. Fish Bull 100:279-298

Olson RJ, Duffy LM, Kuhnert PM, Galván-Magaña F, Bocanegra-Castillo N, Alatorre-Ramirez V (2014) Decadal diet shift in yellowfin tuna Thunnus albacares suggests broad-scale food web changes in the eastern tropical Pacific Ocean. Mar Ecol Prog Ser 497:157-178

Parry M (2006) Feeding behavior of two ommastrephid squids Ommastrephes bartramii and Sthenoteuthis oualaniensis off Hawaii. Mar Ecol Prog Ser 318:229-235

Passarella KC, Hopkins TL (1991) Species composition and food habits of the micronektonic cephalopod assemblage in the eastern Gulf of Mexico. Bull Mar Sci 49:638-659

Pauly D, Trites AW, Capuli E, Christensen V (1998) Diet composition and trophic levels of marine mammals. ICES J Mar Sci 55:467-481
Pauly D, Christensen V, Walters C (2000) Ecopath, Ecosim, and Ecospace as tools for evaluating ecosystem impact of fisheries. ICES J Mar Sci 57:697-706

> Plagányi ÉE, Butterworth DS (2004) A critical look at the potential of Ecopath with Ecosim to assist in practical fisheries management. Afr J Mar Sci 26:261-287

> Polovina JJ (1984) Model of a coral reef ecosystem. Coral Reefs 3:1-11

Polovina JJ, Woodworth-Jefcoats PA (2013) Fishery-induced changes in the subtropical Pacific pelagic ecosystem size structure: observations and theory. PLoS One 8:e62341

Polovina JJ, Howell EA, Abecassis M (2008) Ocean's least productive waters are expanding. Geophys Res Lett 35: L03618, doi:10.1029/2007GL031745

Polovina JJ, Abecassis M, Howell EA, Woodworth P (2009) Increases in the relative abundance of mid-trophic level fishes concurrent with declines in apex predators in the subtropical North Pacific, 1996-2006. Fish Bull 107: 523-531

> Polovina JJ, Dunne JP, Woodworth PA, Howell EA (2011) Projected expansion of the subtropical biome and contraction of the temperate and equatorial upwelling biomes in the North Pacific under global warming. ICES J Mar Sci 68:986-995

> Purcell JE (1991) A review of cnidarians and ctenophores feeding on competitors in the plankton. Hydrobiologia 216:335-342

> Robison BH (2004) Deep pelagic biology. J Exp Mar Biol Ecol 300:253-272

Roemmich D, McCallister T (1989) Large scale circulation of the North Pacific Ocean. Prog Oceanogr 22:171-204

Ruzicka JJ, Brodeur RD, Emmett RL, Steele JH and others (2012) Interannual variability in the Northern California Current food web structure: changes in energy flow pathways and the role of forage fish, euphausiids, and jellyfish. Prog Oceanogr 102:19-41

Seki M, Polovina J (2001) Ocean gyre ecosystems. In: Steele $\mathrm{J}$ (ed) The encyclopedia of ocean sciences. Academic Press, San Diego, CA, p 1959-1964

> Sherwood OA, Guilderson TP, Batista FC, Schiff JT, McCarthy MD (2014) Increasing subtropical North Pacific Ocean nitrogen fixation since the Little Ice Age. Nature 505:78-81

Sibert J, Hampton J, Kleiber P, Maunder M (2006) Biomass, size, and trophic status of top predators in the Pacific Ocean. Science 314:1773-1776

Sieburth JM, Smetacek V, Lenz J (1978) Pelagic ecosystem structure: heterotrophic compartments of the plankton and their relationship to plankton size fraction. Limnol Oceanogr 23:1256-1263

> Sutton TT (2013) Vertical ecology of the pelagic ocean: classical patterns and new perspectives. J Fish Biol 83: 1508-1527

Sutton TT, Hopkins TL (1996) Trophic ecology of the stomiid (Pisces: Stomiidae) fish assemblage of the eastern Gulf of Mexico: strategies, selectivity and impact of a top mesopelagic predator group. Mar Biol 127:179-192

Torres JJ, Belman BW, Childress JJ (1979) Oxygen consumption rates of midwater fishes as a function of depth of occurrence. Deep Sea Res Part A Oceanogr Res Pap 26:185-197

Van Pelt TI, Piatt JF, Lance BK, Roby DD (1997) Proximate composition and energy density of some north pacific forage fishes. Comp Biochem Physiol A Physiol 118: 1393-1398

Walters JF (1976) Ecology of Hawaiian sergestid shrimps 
(Pedaeidea: Sergestidae). Fish Bull 74:799-836

> Watanabe H, Kubodera T, Ichii T, Kawahara S (2004) Feeding habits of neon flying squid Ommastrephes bartramii in the transitional region of the central North Pacific. Mar Ecol Prog Ser 266:173-184

Watanabe H, Kubodera T, Yokawa K (2009) Feeding ecology of the swordfish Xiphias gladius in the subtropical region and transition zone of the western North Pacific. Mar Ecol Prog Ser 396:111-122

Watters GM, Olson RJ, Francis RC, Fiedler PC and others (2003) Physical forcing and the dynamics of the pelagic ecosystem in the eastern tropical Pacific: simulations

Editorial responsibility: Kenneth Sherman, Narragansett, Rhode Island, USA with ENSO-scale and global-warming climate drivers. Can J Fish Aquat Sci 60:1161-1175

Whiteley NM (2011) Physiological and ecological responses of crustaceans to ocean acidification. Mar Ecol Prog Ser 430:257-271

Young RE (1978) Vertical distribution and photosensitive vesicles of pelagic cephalopods from Hawaiian waters. Fish Bull 76:583-615

> Young JW, Lansdell MJ, Campbell RA, Cooper SP, Juanes F, Guest MA (2010) Feeding ecology and niche segregation in oceanic top predators off eastern Australia. Mar Biol $157: 2347-2368$

Submitted: October 5, 2015; Accepted: March 1, 2016

Proofs received from author(s): April 14, 2016 